\title{
Inequality in Higher Education in Greece: Through an Era of Crisis
}

\author{
Souzanna-Maria Nikolaou \\ Associate Professor, Department of Primary Education, University of Ioannina, Greece \\ E-mail: snikola@cc.uoi.gr
}

Monika Papa

Phd, Athens School of Fine Arts, Greece

E-mail: monikapapa@gmail.com

Gloria-Vasiliki Papa

Master in Sociology and Communication, University of Athens, Greece

E-mail: vasilikipap32@gmail.com

Received: May 13, 2019 Accepted: June 14, 2019 Published: July 11, 2019

doi:10.5296/ijssr.v7i2.14772 URL: http://dx.doi.org/10.5296/ijssr.v7i2.14772

\begin{abstract}
The present study explores factors and conditions that make the process of learning difficult and at times problematic for students in the University, through a period of crisis. The survey was conducted at the Department of Primary Education of the University of Ioannina. First-semester students were given a questionnaire, in order to explore their views concerning the factors that inhibit learning in the University. To collect the survey data, an anonymous questionnaire was used that included 44 open and closed-ended questions. There are six sections on the reasons concerning the difficulty of learning: A. Personal Issues B. Multiplicity of Roles C. Issues of Conditions and Learning Environment D. Issues related to the lessons and the classroom. E. Issues relating to teachers F. Quality of teaching and Frequency of attendance. The findings of the survey showed important evidence regarding the conditions that impede students' learning and attendance, highlighting important issues as: learning environment, classrooms, distance from/to the University, and the financial poverty of the students themselves which affects their daily routine. It is primarily noted that at the
\end{abstract}




\section{Macrothink}

time of the crisis we are facing the under-funding of HEIs and this has caused problems. Therefore, the underprivileged and full of disadvantages area of the universities implies poor academic preparation, but also an "unfamiliar" and inappropriate environment of the Institution, which is unable to respond effectively to the needs of students, who are already under financial pressure from their families. These conditions may lead to the well-known situation of students who are "lingering" and probably never acquire their degree, as has been proved by other researchers (The Widening Gap in Higher Education, 1996).

Keywords: low case, comma, paper template, abstract, keywords, introduction 


\section{Introduction}

In a luxurious building on the precincts of Byzantium's royal palaces we find the Magnaura Higher School, 9th century A.D. It is also known as Magnaura University, with an important role in preserving the culture of ancient Greece and the sciences. The operation of the School, the collection of texts and works of the ancient Greek period in its library by the "wise men" of the University of Magnaura, significantly influenced the world of science and knowledge with the most important being the ideas of Renaissance (Protopapas, 2010). (Note 1)

The system of Higher Education in terms of structure, process and relationship of the various mechanisms within the system, has traditionally been shaped in the 12th and 13th centuries. At the Universities of Paris in France (1200), Oxford (1206) and Cambridge (1231) in England (Note 2) and so on. A fundamental element in the decision-making function is the interaction of church and state, a relationship that has become institutional over time and justifies the presence of the church in educational activity to date (the educational activity of the church began in the 3rd century $\mathrm{AD}$ and extends throughout the Middle Ages with the foundation of educational schools in monasteries and dioceses) (Anthogalidou, 2001).

In the post-modern era, Higher Education was affected throughout the Western world by the changes and developments that have taken place and its role has been expanded significantly in the field of research along with that of the transfer of knowledge and the transmission of cultural elements of society to young people, as a preparation for the subsequent assumption of roles in society. Today, universities assemble all the functions associated not only with the transmission of knowledge but also with the production of new knowledge: research, training, training, innovation, lifelong learning.

For these reasons, it was necessary to adapt the existing curriculum structures under the development of new cognitive subjects. Moreover the need for more opportunities for higher education was increased including larger and multicultural population groups, so that universities too, would contribute to a steady growth (Ballantine \& Hammack 2015). Under these circumstances, the model of mass education becomes an international model and a necessary condition, because modern societies and economies of knowledge need citizens who can respond to the new demands of technological developments and scientific knowledge (for the extension of higher education see Kantzara, 2011: 140 et seq.). Historically, the growth of the dynamics of the massification in access to higher education in Greece began in the 1980s, when socio-economic and political-historical developments enabled children from the middle and lower levels of society to be enrolled in higher education (post-conflict and consolidation of democracy, extension of compulsory education, establishment of new university departments) (Kyprianos \& Koniordos, 2003).

Today, universities, not only in Europe but globally, perform functions and roles in direct connection with the evolution and progress of society. They are learning places for the new generation - and not only, areas of culture and knowledge production (and they must be open to all), are directly linked to labor market (Note 3) developments and have been operating in the context of international cooperation in recent years. The purpose of their operation is not only focused on individual cultivation and personality development but also extends to the 
preparation of young people for their professional life, integration into the labor market and addressing the problems they face. This is why emphasis was put on recent years in lifelong learning and self-education as well as in distance learning, and other types of higher education institutions have been developed. It was considered appropriate to differentiate their benefits according to the sector in which they contribute: in the field of science as institutions and centers that generate knowledge through theoretical and applied research, in the professional field as institutions that develop formal qualifications by providing the know-how, lifelong learning as providers of privileges at all ages and in the field of international cooperation as partners and mentors at the level of student development and exchange programs (Unesco, 2002).

In relation to higher education and its rapid development over the last few decades a theoretical reflection has been caused regarding the possibility of access to it and its results.

The main placement of functionalism is based on the view that higher education has been developed to help improve individual opportunities, provide equal opportunities and develop skills to prepare people for integration and adaptation to the ever changing technological and social environment. Therefore, in this perspective, the labor market with the highest demands creates higher cognitive demands for higher education and children from low social strata (if imported), thus solving social problems and ensuring the functioning of society (Parsons, 1959 : 297-318; Ballantine \& Hammack, 2015; Sianou-Kyrgiou, 2005; Lamnias, 2001; Fragoudaki, 1985; Blackledge \& Hunt, 1994; Kyridis ${ }^{2} 2015$, et al.).

Conflict theorists directly link the development of higher education with the needs of the capitalist system to maintain privileged social strata their dominant position within society. Indeed, upward social mobility through the education advocated by theoreticians of functionalism, is claimed to be an illusion that is rarely implemented. This is because the certificates provided by the institutions vary according to the social and professional status of the institution (elitist education) that the student attended. In this way lower strata students graduating from universities are channeled into low-level positions while graduates of well-known and prestigious universities are channeled into high social (and high-paid) positions (Bowles \& Gintis, 1976, Chapter 8 ). Indeed, according to Collins (1978), the requirement for the submission of certificates and diplomas to secure a job does not apply to selecting the most appropriate skills and qualifications but to exclude the person who is considered inappropriate due to lack of certificates. In this way, we are driving the younger generation into an endless effort to acquire diplomas and accumulate certificates in their CV. (Giddens, 2002: 447), inflating the academic requirements for finding a job, but they are inextricably linked to the economy and know-how as characteristics of the labor market and ignore the humanities and social sciences by making Tertiary Education a new big business (Nussbaum, 2013).

And to the point that one of the main challenges for higher education was access to higher education focusing on the issue of massification and reflection on the fact that a more rigorous choice would not be a socially and politically acceptable solution because it involves the basic disadvantage of exclusion of young people from the educational process without a 


\section{Macrothink}

International Journal of Social Science Research

ISSN 2327-5510

2019, Vol. 7, No. 2

diploma and without appropriate training for the labor market (Unesco, 2002), in the years of the economic crisis we face the weakness of the students to be "regular students" (ie attending universities) and moreover they abandon their studies. It is important, of course, to link education to economic growth through the prospect of its impact on it, while at the same time not neglecting its importance for the development of humanity. This is because universities are considered to be privileged environments because of three basic characteristics that define them:

1. include the factor of the human heritage, which is transmitted, renewed and complemented by the production of new knowledge by scientists, teachers and researchers.

2. are interdisciplinary institutions and thus enable the reconciliation and understanding of different cultural elements.

3. have an international communication and interaction capability than any of the other levels of education (Unesco, 2002: 196).

For Greece, the Higher Education system comprises 22 Universities with 268 Departments and 14 TEIs/ Technological educational institutions, with 168 Departments in various counties with branches in the region (Fig. 1). However, especially the newer sections that have been established in recent years are mostly located in the larger cities, namely Athens and Thessaloniki. Among them, the Greek Universities and Technological educational institutions vary in size, time and infrastructure, with a particular focus on their time of operation.



Figure 1. Universities and number of Schools

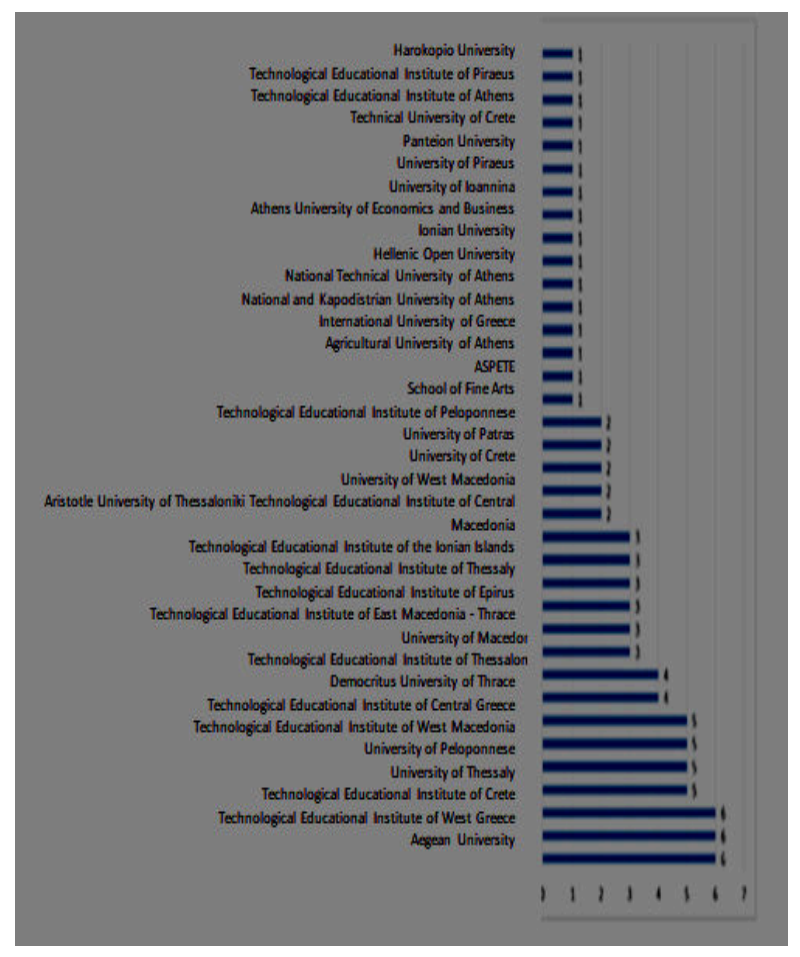

Figure 2. Geographical dispersal of Higher Education 2013-2014

Source: ADIP - Processing - Unit A. Laboratory of the Ministry of Labor and Social Policy (pp. 4), Source: ADIP - Processing Unit A. Laboratory of the Ministry of Labor and Social Policy. 
It is generally estimated that Higher Education in Greece includes a variety of Schools and Departments that cure Sciences (theoretically and positively) in a balanced manner according to the needs of the country (Ministry of Education, Research and Religious Affairs, 2016 at: https: //www.minedu.gov / publications / docs2016/stratigiki_aei.pdf)

Each year students admitting universities amount to 70,000-80,000 with a choice after national exams.

According to the estimates and the evaluation of the ADIP (Unit A, Head of the NSRF-Education Division, Ministry of Education and Research) from the academic year 2003-04 until 2014-15 there is a gradual decrease of the number of regular students by 10,000 students approximately a year, that is directly related to the birth rate and the consequences of the economic crisis affecting the country since 2008. At the same time it is noted that the number of the reduction is doubled in terms of female sex (female students less 18,019 while male students by 10,597 between 2003-04 and 2014-15).

Perhaps the most important element recorded as a result of the economic crisis and the associated unemployment is the number of "lingering students", meaning students who have completed the years of studying according to the time schedule of the faculty attending, but haven't completed successfully their courses in order to obtain their degree, which amounts to 328,742 students for the year 2014-15 (for the year 2003-04 it was 163,037, Ministry of Economy and Finance, 2016). The number has virtually doubled in the last twelve years. It is worth pointing out that amongst the Europe 2020 indicators, it is important to recommend that young people from 30 to 34 years of age have completed Higher Education at a rate of $40 \%$, an indicator not achieved by at least 2015 (with a small difference however).

It is also noted that female gender predominates male in the student population but also in corresponding graduates of undergraduate and postgraduate studies. At the level of doctoral studies, the male gender prevails, with the female is having higher percentages for all students who do not complete their doctoral studies (Ministry of Public Finance, 2016: 13). In general, however, it is noted that the number of postgraduate and doctoral students is gradually increasing from 2003-04 and onwards.

However, the decline in the student population does not seem to go hand in hand with the reduction of teaching staff, especially since the beginning of the financial crisis and beyond. According to the Ministry of Education, a 40\% reduction in teaching staff has been found in universities from 2009-10 to the 2014-15 academic year (2016: 18). The reduction in the strength of teaching staff consists in the non-replacement of retired teachers (permanent teaching staff) in direct connection with the reduction of funds for education, which funded temporary teaching positions at universities and mainly at Technological Institutes.

It could be assumed that the merging of departments and specialized branches (20\%, Ministry of Public Finance, 2016: 20) implemented under the Athena Plan would not result in the large, as it is calculated, issue of the decreasing number of teaching staff in universities and technological institutions. However, the situation of the disproportion of active students and teaching staff was not avoided by the consolidation process, which makes the operation of 
several departments very difficult (2016: 20).

According to the above, the report (Ministry of Education, 2016: 20) of the Ministry of Education for the "strategy of Higher Education in Greece, 2016-2020" notes that there are two conditions that make it difficult for students to attend higher education:

A) The underfunding of higher education in Greece (for its operating expenses and investment needs) of the state budget due to the implementation of consolidation programs to address the financial crisis in the country, which has consequences on the quality of education provided (reduced salaries for the teaching and administrative staff, inadequate funding for maintenance, laboratory equipment, research and teaching infrastructure) (Note 4)

B) Reduction of regular students because of the overall social and economic environment of financial crisis, the deficit student welfare and the shrinkable support of students, with the most prominent effects on students especially from low socioeconomic strata.

\section{Method}

The purpose of the research was to investigate the factors or conditions that make it difficult and problematic to attend the University at the time of the crisis.

\subsection{Design of Research}

The survey was conducted in December 2017 at the Pedagogical Department of Primary Education of the University of Ioannina. For efficiency reasons, first semester students ( $\mathrm{n}=$ 75) were used as a convenience sample, in order to explore their views on obstacles or conditions that make learning difficult at the University.

\subsection{Study Tools}

To collect the survey data, an anonymous questionnaire was used that included 44 open and closed-ended questions. The drafting of the questionnaire was based on the Ballantine \& Feltey (2007) study on factors related to the success or failure of minority students and was adapted to Greek data and conditions. The questionnaire included six sections covering hypotheses about the reasons for learning difficulties and regular student attendance. Learning is hampered by: A. Personal issues of student B. Multiplicity of student roles C. Issues of conditions and learning environment D. Issues related to lessons and classroom. E. Issues relating to teachers F. Quality of teaching and Frequency of attendance. We constructed a five-point scale of answers from None to Too much or from Unacceptable to Very Good.

The bibliography and the use of the pilot questionnaire to the students of the Department were used for the validity of the measuring instrument. The Cronbach's reliability index was 0.732 and is considered satisfactory.

\subsection{Statistical Analysis}

Statistical data was processed through the SPPS21 statistical packet. It was also used the significance level $(p)<0.05$. The analysis of the findings included percentages, range, 


\section{Macrothink}

prevailing value and intermediate value (descriptive statistics).

\section{Results}

The sample students come from different parts of Greece, while the percentage that originates from Ioannina does not exceed a $17 \%$, which allows us to evaluate in the best possible way the reasons for non-regular attendance, when they are not exclusively related to the economic crisis.

By examining the findings of the survey, we underline the following findings:

1. Regarding the obstacles concerning studying and learning at the university, which are part of the student's personal affairs category, the following are observed:

- lack of time as a problem of attendance marks a $10.5 \%$ of the sample, while the majority $(54.7 \%)$ do not seem to be dealing with such a problem.

- lack of money, ie financial issues related to travel expenses to and from the university as a problem of regular attendance, seems to affect (from very to moderate) $48.6 \%$ of the sample.

- moving from another city to attend courses is a matter for only a few students at a mere $5.3 \%$, while the largest percentage of $84.2 \%$ seems to be staying permanently in the city in which their studying.

- As far as the personal attitudes towards attendance, sample students are interested in attending courses (much at 53.9\%, modest $23.7 \%$ ), it does not result from the findings that it is a tedious and painful process. $84.2 \%)$, nor are they bored $(84 \%)$ or have a time management issue $(83.8 \%)$.

\section{Obstacles in Learning Student's personal matters}

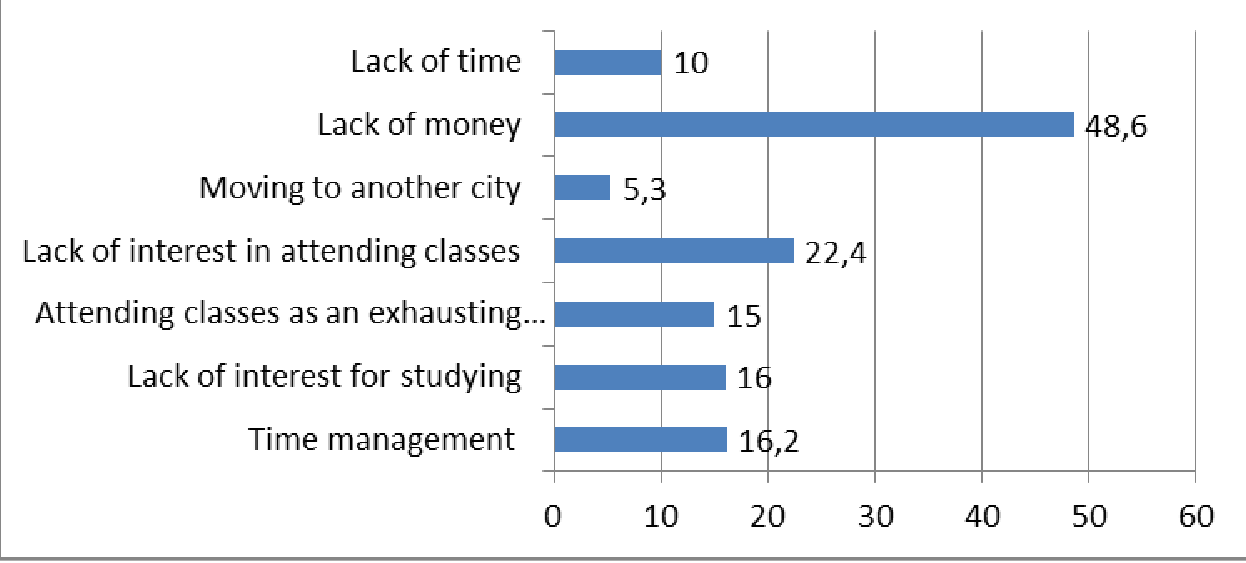

2. Regarding the Conflict of Roles (student and other), where it was investigated whether students have difficulty in attending, because they have other roles (primary or secondary) that require their time and energy, the findings highlight that: 


\section{Macrothink}

- the majority of newly-enrolled students in the sample have not taken on other roles eg to take care of a sick family member or to work or to have other family obligations that deprive them of free time $(95.6 \%)$.

- a significant percentage of the sample seems to spend time on their social life $(51.31 \%)$ and this seems to be a factor that distracts students from regular attendance.

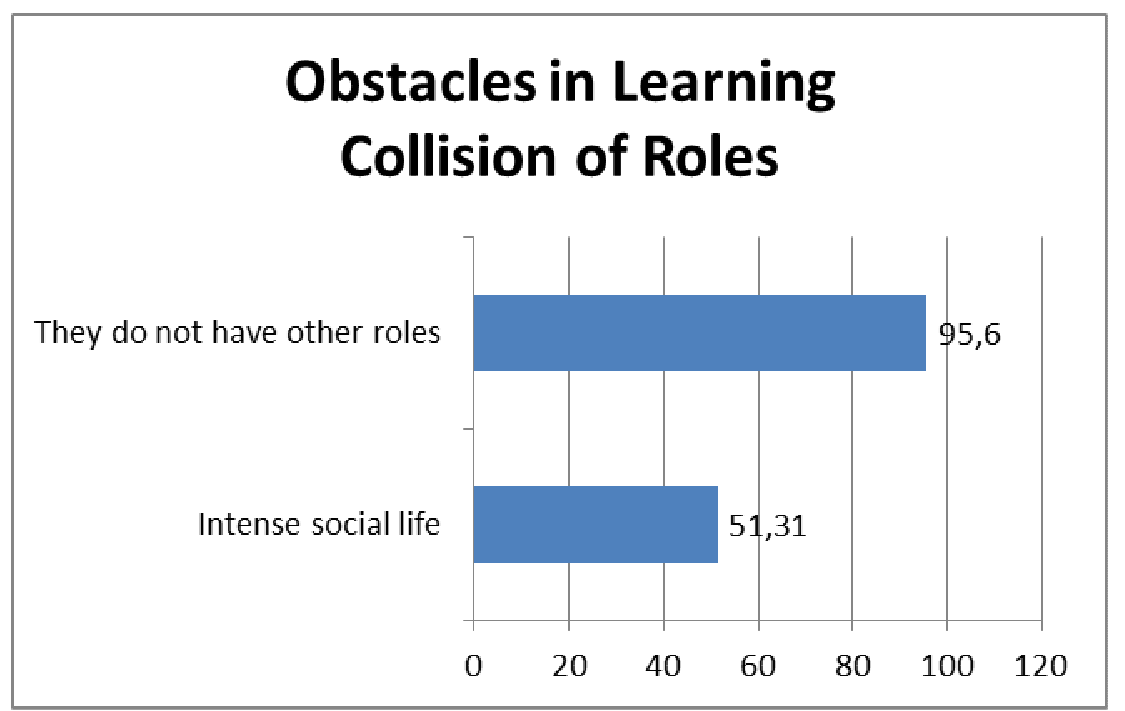

3. Regarding the Learning Environments Issues section referring to the conditions of the learning process, the findings of the survey showed that:

- a large percentage of students find it difficult to attend their studies at the university because of uncomfortable seats $(48.7 \%)$, due to the noise -especially in large auditoriums $(61.9 \%)$, the lack of appropriate temperature in the classroom (42\%) and the higher percentage $(88.5 \%)$ underlines the factor of distance, ie the fact that the university is too far away from the city.

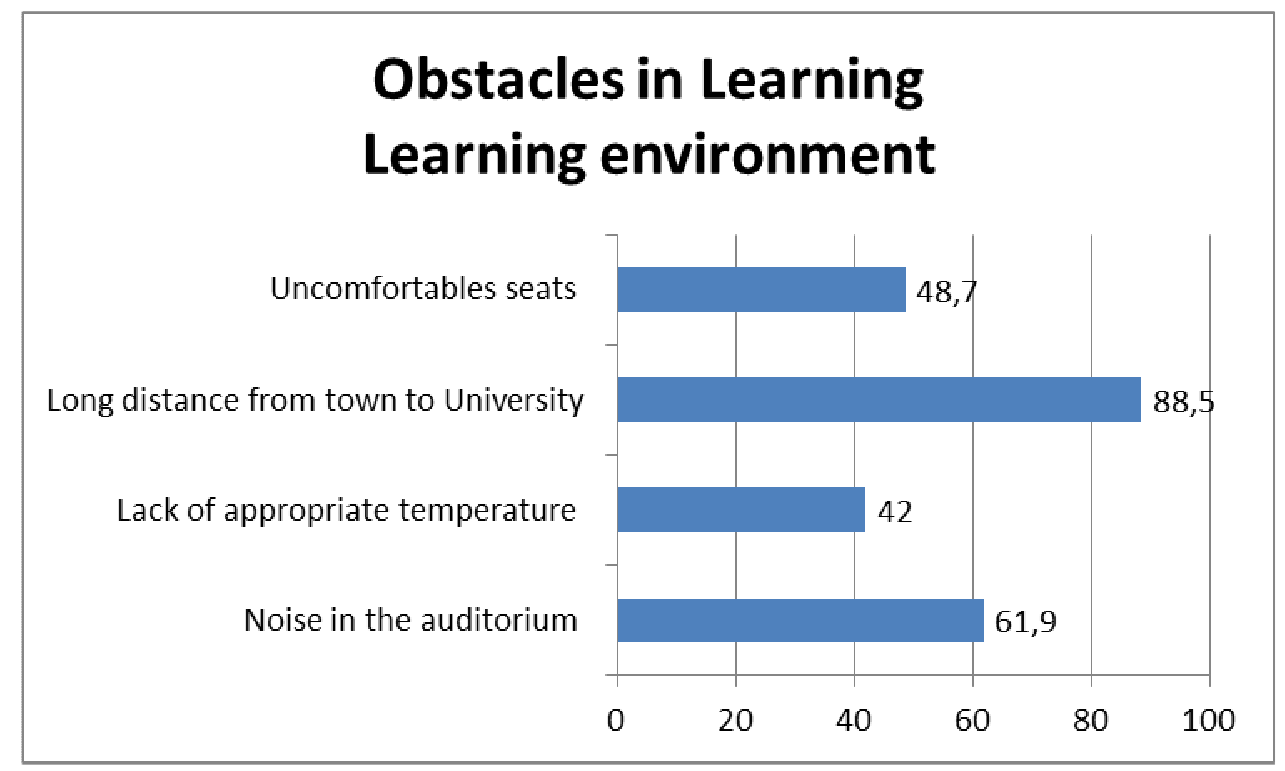

4. With regard to Lesson and Classroom Issues related to teaching practice and workload in relation to time and space, the findings showed the following results: 


\section{Macrothink}

- As to the degree of difficulty of the work and the exercises assigned to them during the semester, the majority $(93.4 \%)$ of the sample considers that the degree of difficulty is small, as opposed to the proportion of students $(6.6 \%)$ who consider the work difficult and hard to understand.

- classes time schedule is a factor that for the majority of the sample is not considered as inappropriate $(76.3 \%)$ and only $23.7 \%$ consider the attending hours to be inconvenient.

- In terms of workload during the course attendance, the majority considered that it was not a particular problem (94.7\%) and only for 5.3\% was considered excessive.

- In terms of teaching rate, only a percentage (13.2\%) considers that it is fast, while the majority considers the course flow to be good.

- Concerning the books, a significant percentage (28\%) think books are boring, while the majority finds them interesting.

- Regarding the cooperation of students among them, they consider to a great extent that when carrying out team projects or group work the cooperation are good and carried out at a good level (lack of cooperative spirit among the students $7.9 \%$ ).

\section{Obstacles in Learning Classes and Teaching Space}

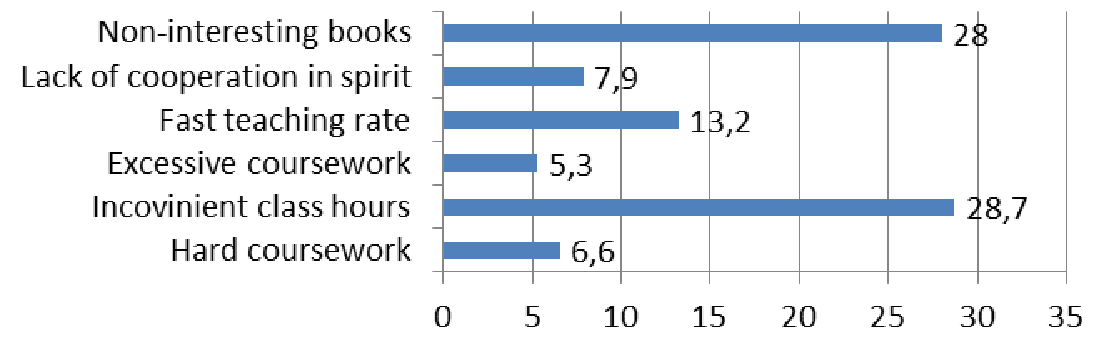

5. Regarding the section teachers' issues, concerning the teacher / trainer teaching image or practice as a factor affecting the student's attendance, it is noted that:

- $92.1 \%$ of the sample students do not believe that the teachers are boring, bad, impersonal and inaccessible, and this is not the factor they are left behind in their studies.

- a significant percentage (28.95\%), however, indicates that their attendance and studies are negatively affected by the teaching style of the teachers, and this does not cause them interest in attending more. 


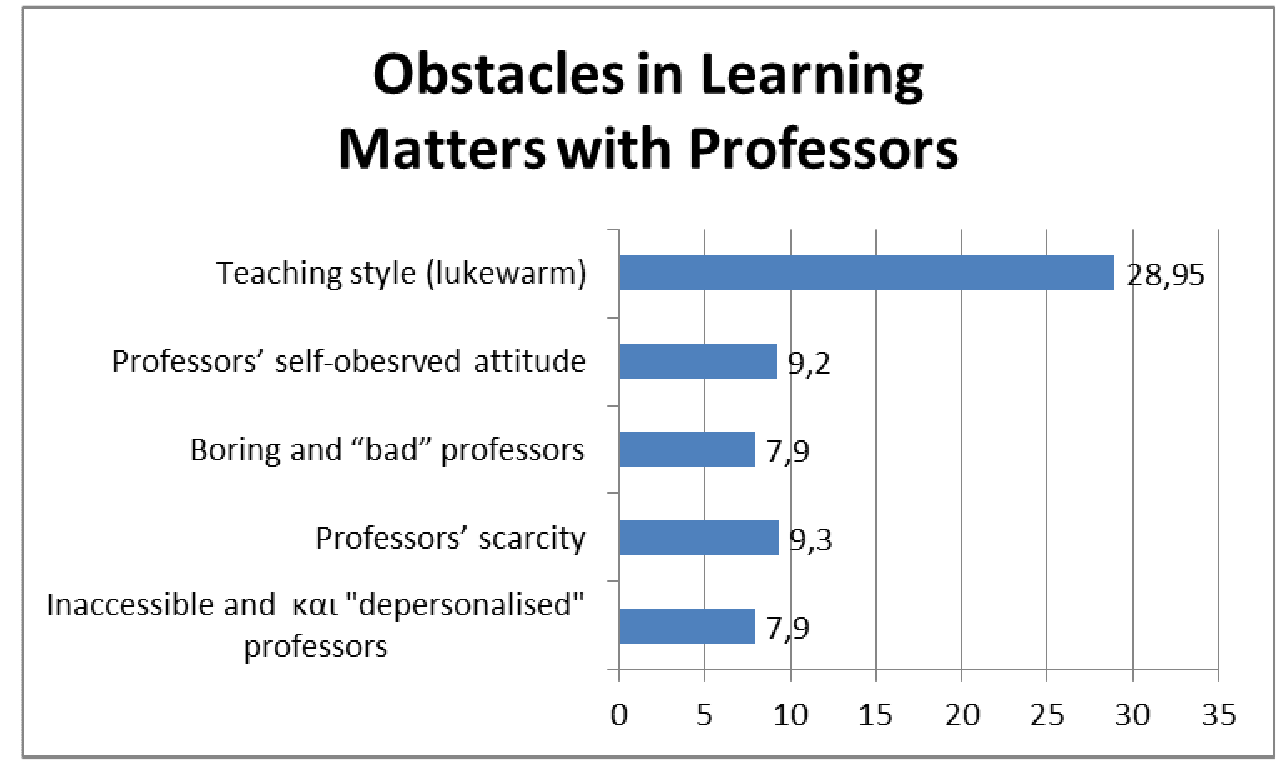

6. Concerning the part related to the quality and timing of the courses taught at the university, the following findings arise:

- students attend the lectures (73.7\%) regularly and the workshops $(54.7 \%)$ and systematically respond to written assignments / exercises assigned to them by the teachers during the semester $(70.7 \% \%)$. However, according to the findings, only a small percentage of the sample (13.1\%) systematically studies the subject matter after each lesson, while it appears that the largest proportion of the sample of new-year students devotes little time (less than two hours a week) the study of specific lessons of the semester.

- students do not attend courses under specific circumstances, such as the participant's health issues $(40.8 \%)$ or the study for a difficult lesson $(47.4 \%)$;

- the obligation to attend a course does not seem to affect the attendance, since $69.7 \%$ of the sample asserts that it is not affected by the attendance of a course, whether it is compulsory or not.
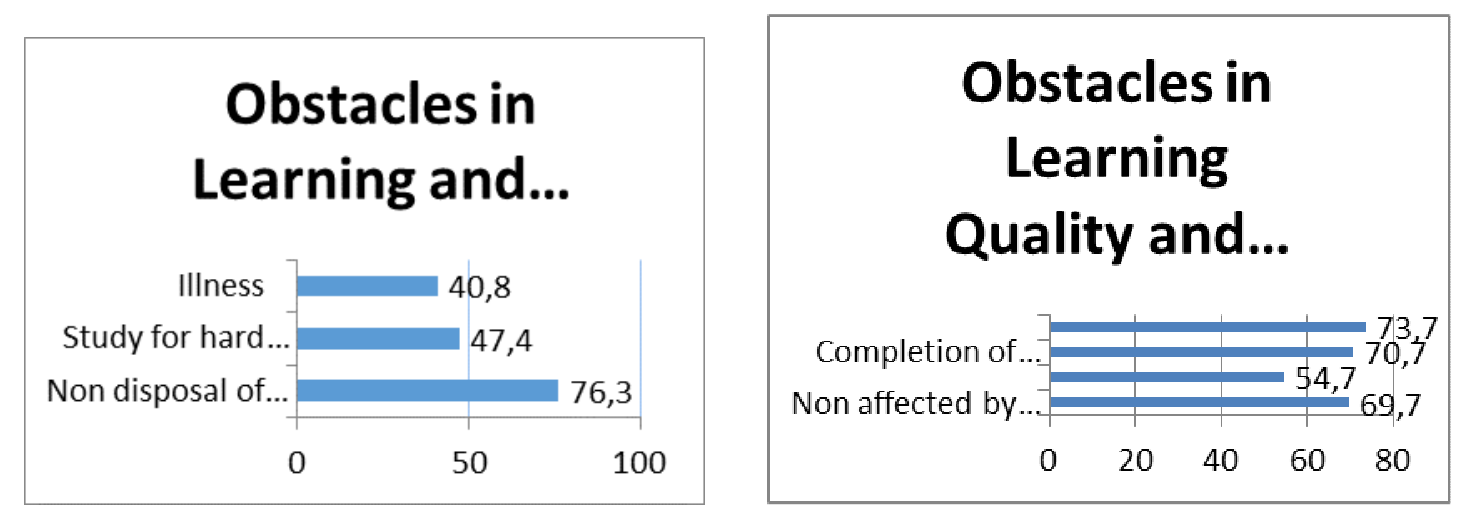

Restrictions of the research

Although the research offered important data on conditions that impede students' learning and attendance, however, the number of the sample was small, on the other hand it was limited to 
a sample by a single Department, which does not allow generalizations. It would be advisable to further explore the subject in a larger sample of all universities in Greece and study and research in all years (semesters) of study. Possibly the questionnaire could also include questions about the socio-economic profile of the students, which would make multifactorial analyzes feasible, so as to prove the relationship between social class and "tagging", with success and regular attendance of students in the University.

\section{Discussion}

It is a fact that in Greece we are confronted by the crisis with all the implications that this entails. Today's students belong to a different generation than the age of prosperity. They have experienced difficult situations in pre-pubertal and teenage years with anxiety and frustration; they have faced issues they could not find a direct solution: destabilization, economic tightness, uncertainty, perhaps unemployment and poverty. It is the generation of young adults today who grew up in the crisis. Their transition to adult life was deeply rooted in the treaty of instability, lack of stability and permanence, and significant financial shortcomings that also affected the quality of family life. The fact that they excelled in national exams and achieved a place as students at the university is not enough to ensure stability in their lives. It is the beginning of a survival struggle that begins at the start of the first academic year and depends primarily on the financial capacity of the family for the preservation of a child as a student in a city other than that of a permanent residence (Chrysakis \& Baldourdos, 2006, Baldourdos \& Petraki, 2012).Higher education, therefore, is not only based on individual desires, aspirations and abilities, but as it is also found in the social stratum that defines cultural and economic capital. The latter two factors create different disadvantages and advantages in the child's environment and influence their learning and academic development (Htouris, 2012). More specifically: Firstly, children have to face the issue of success or failure to succeed in the national exams and enter the university. Once enrolled in tertiary education, they encounter obstacles to learning caused by their background (to which specific factors such as character, knowledge, experiences and situations they have experienced), the socio-economic position of the family and the school or department where they are attending.

According to the findings of our research, the first year students have a good background (as mentioned above), which is underlined by the fact that a large percentage $(73.7 \%)$ finds interest in attending lessons without considering it to be a tedious or painful process, they are not bored to read nor they dislike reading (85\%). In addition, our research has shown that students do not attend courses only in cases depending on an unpredictable factor such as, for example, illness or when they have to study for a difficult lesson. Also, the fact that the obligation to attend a lesson is not an important factor for attending (69.7\%) is another confirmation of the level and background of our students. Students as a social group, as confirmed by surveys, come mainly from families belonging to the middle classes (Sianou-Kyrgiou, 2005, 104). The children of laborers or poor workers were studying in universities, generally and internationally (Metcalf, 1997), in a small percentage compared to middle and upper-middle class children at a time when the financial crisis had not yet hit Greece. At the time of the crisis, the disadvantages of the low-income classes have increased (and the middle and lower social class have become poorer), affecting access to higher 
education, in the first place. In the second place, those same disadvantages also affect students as to regular attendance. Therefore, because of the findings of the research, the cultural capital of the first-year students is high, with reference to the factors of the personal attitude to attendance and to knowledge, it is concluded that the students certainly do not come from a deprived background.

It is worth mentioning that most students $(84.2 \%)$ stay permanently in the city of study and do not move, they also do not work $(90.8 \%)$, do not have family responsibilities $(94.7 \%)$ or have assumed other roles (e.g taking care of a family member of 96.5\%). Excluding the number of students facing financial problems (20.7\%), it is clear that most of the students do not face personal problems that might affect their regular attendance at university as possible factors. However, a significant percentage of students with limited financial resources are being identified, for whom, as other surveys show, graduation will be anyway a difficult achievement (Levine, 1995; Hurado \& Carter, 1997; Mortenson, 2005).

One issue of concern is the fact that students regularly attend lectures, workshops and respond to written assignments in a large percentage (69.7\%), but they do not systematically study the subject after each lesson and devote a minimum of study time per week. Also, while social life seems to be an important factor in failing from regular attendance $(51.39 \%)$, however, sport, internet and social media or television are not included in their social extra-curricular activities, and this is an important element that suggests further investigation.

Regarding the factors involved in regular attendance and related to the operation of the School or the Department, it is established that the under-funding of Universities has caused problems. This is because a significant percentage of students (over 75\%) have no problems with attendance and regular study with regard to professors (eg, they are impersonal, inaccessible, bad, boring) or degree difficulty or the workload of the exercises assigned to them but also as to the timing of the courses, seminars or workshops. Instead, according to the findings, students are pleased with the teaching and the rhythm of teaching, the books they are provided with and find them interesting, but also from their co-student cooperation. However, with regard to the learning environments including the conditions of the learning process, a significant amount of obstacles are encountered in their regular attendance, resulting from uncomfortable seats $(48.9 \%)$, the lack of appropriate temperature in the classrooms (41.98\%) from the noise in large rooms, when many students $(61.85 \%)$ are being gathered for class. Even the fact that the campus is located at a distance from the city center, it affects negatively regular attendance $(88.42 \%)$. It can be seen that the latter factors are directly related to the economic poverty that the universities have suffered and which suggests poor academic preparation and a bad climate in the School which is unable to respond effectively to the needs of students already under financial pressure from their family due to underfunding. These conditions may lead to the well-known situation of students who are "lingering" and probably never acquire their degree, as has been proved by other researchers (The Widening Gap in Higher Education, 1996).

Considering the findings of research, we believe that policies and practices used for universities must be directly linked to the role or roles played by the university in a country. The biggest problem faced by education was that of difficulty or inability to learn, especially 
for children from deprived social and cultural backgrounds. Beyond the limits of normal or acceptable in times of economic crisis, when the struggle that a young adult needs to overcome for a university placement in the National Exams has also to face obstacles in attending and learning within the Highest Education due to lack of funding. If the latter prevails as a rule for the next a decade, then one more point is made of the power of social and economic inequality in favor of the upper economic strata, whose children will even study in private universities, while children of low social classes even if they earn a position as students will never finish their studies.

We hope that the reaction will also come from the students themselves (Note 5). Higher education students, despite the collapse of the syndicalism (Note 6), are now more aware of social movements that did not appear before the crisis (e.g collapse of the middle class, protection of the ecosystem, human rights, etc.). ). They have a large pool of political and social experiences that makes them fighters, as a generation, more than ever. The older generation owes a debt to young people: to respond as best and with greater understanding to the effort made to create prospects for transformation and to devise new ways and practices of addressing social life issues. From this perspective, we must redefine the mission of the university for society and strengthen it as the dominant body that guarantees global human values and cultural capital (a public good that concerns all education) and not as an institution that serves the logic of public service and of labor market (Unesco, 2002).

\section{References}

Anthogalidou, Th. (2001). Sociological Studies Retrieved from http://www.auth.gr/virtualschool/2.2-3/TheoryResearch/AnthogalidouSocioStudies.html/20.0 3.2004

Ballantine, J., \& Feltey, K. (2007). Factors Related to Minority Student Success of Failure, Paper presented at the North Central Sociological Association Meetings, Chicago IL.

Ballantine, J., \& Hammack, F. M. (2015). Sociology of Education. A systematic analysis, e. D. Gouvia, Ms. Y. Kosma, P. Kourmetalla, Thes: Center.

Balourdos, D., \& Petrakis, M. (2012). (Eds.). New poverty and social exclusion. Counterfeiting Policies and the Establishment of a Minimum Guaranteed Income, Athens: Greek Parliament.

Baskozos, G. (2006). Student Movement May-June: We Win, Continue!, Education and Society 19, December.

Bowels S., \& Gintis, H. (1976). Schooling in Capitalist America. London: Routledge and Kegan Paul.

Chryssakis, M., \& Balourdos, D. (2006). Educational Dimensions of Poverty and Social Exclusion. Proceedings of the International Conference "Poverty, Exclusion \& Social Inequalities", EKKE - Social Policy Institute, Lavrio, 22-23 September.

Collins, R. (1979). The Credential Society: An Historical Sociology and Stratification. New 
York: Academic Press.

Fragkoudaki, A. (1985). Sociology of Education. Theories of Social Inequality in School. Athens: Papazisis.

Giddens, A. (2002). Sociology, ed. Tsaousis, Athens: Gutenberg.

Hturis, S. (2012). The dimensions of poverty and social exclusion in Greek youth: policies for the transition from education to employment and working life. In D. Balourdos \& $\mathrm{M}$. Petrakis (Eds.), New poverty and social exclusion. Combating Policies and Establishing a Minimum Guaranteed Income (pp. 85-94). Athens: Greek Parliament.

Hurado, S., \& Carter, D. F. (1997). Effects of College Transition and Perceptions of the College Racial Climate on Latino College Students' Sense of Belonging. Sociology of Education, 70(4), 324-345.

Kantzara, B. (2011). The boundaries of education. Essays. Athens: interaction.

Koutoufari-Malandrinou, I. (2011). The century of sovereignty: state or university?, File archive, 1, 124-20.

Kyprianos, P., \& Koniordos, M. (2003). The demystification of the university: eternal students and abandonment of studies. Modern Education magazine, 132, 23-34.

Kyridis, A. (2015). Educational Imbalance. Delimitation and attempts of its theoretical approach, Bd. Thessaloniki: Kyriakidis.

Lamnias, K. (2001). Sociological Theory and Education. Discreet Approaches, Athens: Metechmio.

Levine, A. (1995). Beating the Odds: How Do the Poor Get to College. San Francisco, CA: Jossey-Bass.

Louloudis, L. (2007). Our Lost Universities. A Review of Higher Education Reform. Science and Society, Political and Ethical Theory Review, 17, 277-287.

Metcalf, H. (1997). Class and Higher Education. The participation of young people from lower social classes. London: Policy Studies Institute / CIHE.

Mortenson, T. (2005). Family Income and Higher Education Opportunity 1970 to 2003. Postsecondary Education Opportunity, N. 162, pp. 1-7.

Nikolaou, S.-M., Papa, M., \& Gogou, L. (2018). Social inequalities in a time of economic crisis in Greece. International Journal of Social Science Research, 6(1). https://doi.org/10.5296/ijssr.v6i1

Nussbaum, M. (2013). Not for Profit. Humanitarian Studies Promote Democracy, Chr. Tsironis, Ms. G. Christidis, Athens: Criticism.

Parsons, T. (1959). The school class as a social system: Some of its functions in American society. Harvard Education Review, 29(4), 297-318. 


\section{Macrothink}

Protopapa, A. (2010). University of Magnaura. Spiritual Lighthouse, in: "Attensions", Periodical Version of the Holy Metropolis of Kykkos and Tyllyria, Issue 10th, January - April 2010.

Psarrou, M. K., \& Zafiropoulos, K. (2001). Scientific research. Theory and Applications in Social Sciences. Athens: Typothito, G. Dardanos.

Sianou-Kyrgiou, E. (2005). Education and social inequalities. The transition from secondary to higher education (1997-2004). Athens: Metechmio.

Taousanis, Chr. \& Kotios, K. (2014). Programs and Directions Provided in Greek Higher Education, Employ, Advisory Training and Career Company, e-employ.gr (21/12/2017).

Unesco. (2002). Education in the 21st Century under the chairmanship of Jacques Delors, Working Group of the Center for Educational Research, M. Kassotakis, Athens: Gutenberg.

\section{Copyrights}

Copyright for this article is retained by the author(s), with first publication rights granted to the journal.

This is an open-access article distributed under the terms and conditions of the Creative Commons Attribution license (http://creativecommons.org/licenses/by/4.0/). 